\title{
Should I Stay or Should I Go: Student Housing, Remote Instruction, Campus Policies and COVID-19
}

\author{
Patricia E. Salkin \\ Touro Law Center, psalkin@tourolaw.edu \\ Pamela Ko
}

Follow this and additional works at: https://digitalcommons.tourolaw.edu/scholarlyworks

Part of the Civil Law Commons, Contracts Commons, Courts Commons, Education Law Commons, and the Health Law and Policy Commons

\section{Recommended Citation}

Patricia E. Salkin \& Pamela Ko, Should I Stay or Should I Go: Student Housing, Remote Instruction, Campus Policies and COVID-19. 50 URB. LAW. 371 (2020).

This Article is brought to you for free and open access by the Faculty Scholarship at Digital Commons @ Touro Law Center. It has been accepted for inclusion in Scholarly Works by an authorized administrator of Digital Commons @ Touro Law Center. For more information, please contact Iross@tourolaw.edu. 


\title{
Should I Stay or Should I Go?: Student Housing, Remote Instruction, Campus Policies, and COVID-19
}

\author{
Patricia E. Salkin* and Pamela Ko**
}

\section{Introduction}

In March 2020, as the world scrambled to understand and address myriad public health and economic challe ges unfolding from the novel coronavirus labeled COVID-19, higher education was forced into a tailspin. ${ }^{1}$ In many respects, large residential colleges and universities operate like mini cities. ${ }^{2}$ The $\mathrm{p}$ esident of the campus functions similarly to a mayor, with the Board of Trustees and representative faculty body serving similar poli y making roles as that of the city council. ${ }^{3}$ While the city budget generates the overwhelming bulk of its revenue from the tax $b$ se, a typical campus generates its revenue from tuition, housing fees and related food services income, and larger schools rely on ticket sales and licensing fees associated with various athletic events. ${ }^{4}$ Although the tax sales revenue anticipated

\footnotetext{
*Patricia E. Salkin is Senior Vice President for Academic Affairs for the Touro College and Unive sity System and Provost for the Touro College Graduate and Professional Divisions She is a former Dean of the Jacob D. Fuchsberg Touro Law Center.

**Pamelo Ko, E q. was an Associate Professor of Law in the School of Managemen at Russell Sage College.

1. Lilah Burke, Leading the Pack, Insider Higher Educ. (Oct. 26, 2020), https://ww insidehighered.com/news/2020/10/26/colleges-high-case-counts-show -n -sig s-shutting-down.

2. Katie Pyzyk, How Universities' Smart Campuses Resemble Mini Smart Cities, SMARTCITIESDIVE (Feb. 16, 2018), https://www.smartcitiesdive.com/news/how unive sities-smart-campuses-resemble-mini-smart-cities/517016.

3 K. Johnson Bowles, The President's Many Roles, Inside Higher Educ. (July 1, 2013), https://www.insidehighered.com/advice/2013/07/01/many-roles-and expectations-college-presidents-essay.

4. Victoria Yen, Mounting Peril for Public Higher Education During the Coronavirus Pandemic, CTR. FOR AM. Progress (June 11, 2020), https://www.amer ican progress.org/issues/education-postsecondary/reports/2020/06/11/485963 /mounting-peril-public-higher-education-coronavirus-pandemic. Bymid-December 2020, at least 6,629 cases of COVID-19 had been reported in athletic programs of the top tier of college athletics. See, Alan Blinder, Lauryn Higgins \& Benjamin Guggenheim, College Sports Has Reported at Least 6,629 Virus Cases. There
} 
by many cities has suffered during shelter-in-place orders, the property tax remains a steady receivable, even if delayed. The economic outlook for many colleges and universities is more dire. ${ }^{5}$ Higher education is a fee-for-service enterprise, and when certain services ar unavailable, certain fees cannot be collected. ${ }^{6}$ While delivery of the academic curriculum continued through remote instruction, which justified the continued collection of tuition, when room and board fees are affected because student housing is not available $\mathrm{r}$ is significantly reduced, this has a major economic impact o the campus budget. $^{7}$ For example, in December 2020, the Unive sity of Massachusetts projected a $\$ 335$ million shortfall due primarily to the loss of student housing and dining revenue. ${ }^{8}$ This is not surprising since, soon after the pandemic began to rage across the country, a survey of 192 college and university presidents conducted in April 2020 by the American Council on Education revealed the severe economic challenges institutions predicted they wou $\mathrm{d}_{\text {face }}{ }^{9}$

Are Many More, N.Y. Times (Dec. 11, 2020), https://www.nytimes.com/2020/12/11 /sports/coronavirus-college-sports-football.htm Of course, there are other sources of revenue such as philanthropic suppor which also saw a decline during the pandemic, and investment portfolios, which $\mathrm{h}$ e continued to be on a rollercoaster throughout the pandemic owing to national politics and news of vaccines, shutdowns, and infection rates.

5. Doug Lederman, COVID-19 Forceful Financial Hit: A Survey of Business Officers, Inside Higher Edu (July 10, 2020), https://www.insidehighered.com /news/survey/covid-19s-forceful-fin ncial-hit-survey-business-officers. In December 2020, George Washington University announced the layoff of 339 employees to help mitigate the financial impact of the pandemic, saving \$32 million which is only 18 percent of the University's projected annual budget gap. See Zach Schonfeld, Official Conclude Expected Layoffs as Part of COVID-19 Financial Mitigation, GW Hatcheт (Dec. 11, 2020), https://www.gwhatchet.com/2020/12/11 /officials-conclude-expected-layoffs-as-part-of-covid-19-financial-mitigation.

6. Mark Lieberman, Competing Models Among OPM Providers, Inside Higher EduC (Oct. 25, 2017), https://www.insidehighered.com/digital-learning /article/2017/10/25/ pms-fee-service-growing-revenue-share-models-dominate.

7. Konrad Putzier, COVID-19 Outbreaks Spell Trouble for Student-Housing Owne Wall ST. J. (Sept. 8, 2020), https://www.wsj.com/articles/covid-19 -ou breaks pell-trouble-for-student-housing-owners-11599566400.

8. Pr ss Release, University of Massachusetts, UMass Confronts Evolving Pan emic Fiscal Pressures (Dec. 9, 2020), https://www.massachusetts.edu/news /um ss-confronts-evolving-pandemic-financial-pressures.

9. Jonathan Turk \& Darsella Vigil, College and University Presidents Respond to COVID-19: April 2020 Survey, Am. Council on Educ. (Apr. 23, 2020), https:// www.acenet.edu/Research-Insights/Pages/Senior-Leaders/College-and-University Presidents-Respond-to-COVID-19-April-2020.aspx. Presidents noted the six most pre ing issues that they are facing during COVID-19 were fall or summer enrollment (86\%); long-term financial viability (64\%); sustaining an online learning environment ( $45 \%)$; laying off faculty and staff (44\%); mental health of students (41\%); short-term financial viability $(37 \%)$. 
Host communities to college campuses across the country have also been impacted in many ways, both with and without a student presence on campus during the pandemic. ${ }^{10}$ When physical campuses are closed and classes are offered through remote instr ction, landlords, restaurants, bars, and stores frequented by students suffer a loss of revenue when some of the students decide not to return to campus due to remote options. ${ }^{11}$ For those neighborhoods where college students decide to return, the fear and anxi ty of full-time community members rise due to the often invinc ble and risk-taking attitudes of the twenty-something age group wh have proven to be super-spreaders of the virus in some colleg towns. ${ }^{12}$ As we look to future academic semesters, schools are hoping to bring students back to campus housing safely, based on lessons learned during the pandemic. ${ }^{13}$

This article examines the legal and policy challenges that result from, among other issues, the congregate housing situations existing for on- and off-campus housing at colleges and universities. The legal issues demonstrate federa ism at work and include; at the federal level, regulations an guidance from the White House, the Center for Disease Control (CDC) and the U.S. Department of Education; at the State level from gubernatorial executive orders, state departments of education and state health departments; and at the local governme $t$ level from mayoral executive orders and local public health offices. Part II discusses the shift to remote instruction in higher education beginning in March 2020. Section A sets forth the regula ory landscape leading to remote instruction, and Section B discusses housing challenges from the Spring 2020 semester that in luded closing campus housing and sending students home as well a issues related to the departure of students for spring break who received emails once off-campus stating that they could not retu $\mathrm{n}$ to campus to retrieve their belongings for an unknown

10. And ew DePietro, COVID-19 Outbreaks Are Wreaking Economic Havoc on College Towns, Forbes (Oct. 26, 2020), https://www.forbes.com/sites/andrew depiet o/2020/10/26/covid-19-outbreaks-are-wreaking-economic-havoc-on-col leg -towns/?sh=370fbf0ala68.

11. Id.

12. Sarah Watson, Shawn Hubler, Danielle Ivory \& Robert Gebeloff, A New Front in America's Pandemic: College Towns, N.Y. Times (Sept. 6, 2020, updated Sept.10, 2020), https://www.nytimes.com/2020/09/06/us/colleges-coronavirus-stu dents.html.

13. Anemona Hartocollis \& Shawn Hubler, Some Colleges Plan to Bring Back More Students in the Spring, N.Y. Times (Dec. 6, 2020, updated Dec. 9, 2020), https://www.nytimes.com/2020/12/06/us/colleges-covid-spring-semester.html ?referringSource $=$ articleShare. 
period of time. The legal issues surrounding the return of fees such as those pre-paid for housing and food services is addressed, and the rise of class action lawsuits is discussed. Part III examines some approaches campuses took for reopening in the Fall 2020 semes ter, analyzing COVID-19 testing generally, enforcement of camp s policies, student violations, and COVID-19 transmission related to congregate housing. These approaches were influenced by CDC guidance for higher education, state specific reopening guidance and other business, health, and education regulations apply ng to higher education. This section also looks at strategies bei $\mathrm{g}$ created and implemented to allow institutions to open/reopen in the Spring of 2021. Part IV concludes with thoughts about the future of higher education as campuses continue to navigate th ough a COVID and post-COVID landscape.

\section{COVID-19 Declared a Pandemic in March 2020}

While the earliest cases of COVID-19 in the United States can be traced to late January and early Febru y 2020, ${ }^{14}$ on March 11, 2020 the World Health Organization decl red COVID-19 a pandemic. ${ }^{15}$ The president declared a natio al em rgency on March 13, 2020 and began to free up federal resour s to combat the spread of the virus. ${ }^{16}$ The White House Coronavirus Task Force, which was established in January 29, 2020, ${ }^{1}$ had already been evaluating necessary steps and recommendations to slow the spread of the virus. On March 18, 2020, the president signed a coronavirus relief package that provided for free testi $g$ and emergency paid leave, and by April

14. Mike Baker, When Did the Coronavirus Arrive in the U.S.? Here's a Review of the Evidenc N.Y. Times (May 15, 2020, updated June 1, 2020), https://www .nytimes com/2020/05/15/us/coronavirus-first-case-snohomish-antibodies.html.

15. World Health Organization, WHO Director General's Opening Remarks at the Media Bri fing on COVID-19 - 11 March 2020 (Mar. 11, 2020), https://www .who int/di ector-general/speeches/detail/who-director-general-s-opening-remarks -at e-media-briefing-on-covid-19---11-march-2020.

16. White House, Proclamation on Declaring a National Emergency Concerning he Novel Coronavirus Disease (COVID-19) Outbreak (Mar. 13, 2020), https:// www.whitehouse.gov/presidential-actions/proclamation-declaring-national-emer gency concerning-novel-coronavirus-disease-covid-19-outbreak.

White House, Statement from the Press Secretary Regarding the Presidents Coronavirus Task Force (Jan. 29, 2020), https://www.whitehouse.gov /briefings-statements/statement-press-secretary-regarding-presidents-coronavi rus-task-force. 
2020, the president recommended masks be worn when social distancing guidelines could not be followed. ${ }^{18}$

Although most closure orders for institutions of higher ducation were state-based, federal guidelines and recommendations were provided to assist states in these efforts. On March 17 2020, the U.S. Department of Education (DOE) issued a let er indicating that, as a result of the pandemic, it was extendi $g$ lexibility to accreditors and to schools to allow for the cu riculum to be delivered in a distance education format even $\mathrm{f}$ the program had not been previously registered for such form t. ${ }^{19}$ On April 3, 2020, the U.S. DOE issued additional guidelines which, among other things, extended flexibility to colleges and universities relating to adjustments in the academic calendar, policies governing leaves of absence, and the ability for institutions $t$ allow their students to complete courses at other institut ons without physically returning to the home campus. ${ }^{20}$ In May 2020, he Office of Civil Rights at the DOE issued guidance reminding schools that student civil rights were still to be protected in the pivot to distance education format; meaning, among other hings, that the distance education format must accommodate students with disabilities. ${ }^{21}$ On May 15, 2020, the DOE extended he distance education format flexibility through December 20,2020, a d extended the flexibility to accreditors unable to complete in-person site visits. ${ }^{22}$

The Center for Disea e Control and Prevention (CDC) also provided recommendations and guidance for institutions grappling with the complexities of campus closures. The CDC website includes a

18. Centers for Disease Control and Prevention, Considerations for Wearing Masks (updated Dec. 7, 2020), https://www.cdc.gov/coronavirus/2019-ncov/pre vent getting-sick/cloth-face-cover-guidance.html.

19. U S. Dep't Educ., Office of Postsecondary Education, Information for Accrediting Agencies Regarding Temporary Flexibilities Provided to CoroNA IRUS Impacted Institutions or ACCRediting Agencies (Mar. 17, 2020), https:// www2.ed.gov/about/offices/list/ope/20-007covid19accreditorsfromomb317s.pdf.

20 Office of Postsecondary Education, UPDATED Guidance for interruptions of study related to Coronavirus (COVID-19), U.S. Department of Education (April3, 2020), https://ifap.ed.gov/electronic-announcements/040320UPDATEDGuidance InterruptStudyRelCOVID19.

21. Office for Civil Rights, Questions and Answers for Postsecondary Institutions Regarding the COVID-19 National Emergency, U.S. Department of Education (May 12, 2020), https://www2.ed.gov/about/offices/list/ocr/docs/20200512-qa-psi -covid-19.pdf.

22. Office of Postsecondary Education, UPDATED Guidance for interruptions of study related to Coronavirus (COVID-19), U.S. Department of Education (updated June 16, 2020), https://ifap.ed.gov/electronic-announcements/051520UP DATEDGuidanceInterruptStudyRelCOVID19May2020. 
coronavirus dashboard with information for the operation of institutions of higher education..$^{23}$ The dashboard highlights relevant considerations for both closures and reopenings, such as testing for on-campus and off-campus students, mitigation strategies to us when an institution is open, and information on when and how $o$ isolate or quarantine students and staff, if necessary. ${ }^{24}$

The CDC's recommendations make it clear that the likelih od of spread in a community is directly affected by the number of people that interact in close proximity over an extended period of ime. ${ }^{25}$ The dashboard offers information on mitigation st ategies such as mask-wearing, social distancing, and basic hygiene. ${ }^{26}$ Recommendations and guidelines for institutions of higher education (IHEs) focus on communicating information on infect on within communities and the importance of compliance with mitigation strategies. ${ }^{27}$ The CDC also recommends that IHEs communicate their selected level of risk so that people can make more nformed decisions about attendance, "especially those with disabilities and people who are at higher risk of severe illness from COVID "28 Moreover, the dashboard highlights important statistics $r$ lated to the risk of COVID spread in IHE non-residential (.e., off-campus housing) and residential (i.e., on-campus housing) ettings within a larger community setting. ${ }^{29}$

On October 5, 2020, th CDC updated the considerations IHEs should evaluate when determining the best course of action in reopening institutions as well as keeping IHEs open. ${ }^{30}$ According to the CDC, an IHE's response to several factors should be constantly evaluated and updated as needed. ${ }^{31}$ These factors include building

23. The Cen $\mathrm{r}$ for Disease Control and Prevention, Colleges, Universities, and Higher Learning Pl n Prepare, and Respond (Nov. 16, 2020), https://www.cdc.gov /coronavirus/2019-ncov/community/colleges-universities/index.html.

24. The Center for Disease Control and Prevention, COVID-19 Guidance for Shared or Congregate Housing (updated Aug. 22, 2020), https://www.cdc.gov/coro navirus/2019-n ov/community/shared-congregate-house/guidance-shared-congre gate housing html.

2 The Center for Disease Control and Prevention, Considerations for Institutions of Higher Education (Dec. 3, 2020), https://www.cdc.gov/coronavirus /2019-ncov/community/colleges-universities/considerations.html\#principles.

26. $I d$.

27. $d$.

2 Id.

29. $I d$.

30. $I d$.

31. Id. 
ventilation, food service, contact tracing, screening, testing, and coping support for students and staff. ${ }^{32}$

\section{A. State Regulations and the Shift to Remote Learning}

In addition to the various federal agency guidelines and recommendations, starting in early March 2020, states also provided information and guidance to IHEs on required closings ${ }^{33}$ Colleges and institutions throughout the nation were required to close in response to various gubernatorial executive orders even a hes institutions attempted to keep up with various state reg ations and guidelines which were rapidly being released and updated in response to new information. These unanticipated closu es, and the resulting calls for improved remote instruction and technical assistance, access to personal belongings left on campus, and refunds for tuition, student fees, room and board, posed signif cant challenges for most institutions.

In New York, Governor Andrew Cuomo issued Executive Order Number 202 on March 7, 2020 decl ring a state of emergency and closed all non-essential businesses effective March 22, 2020. ${ }^{34}$ Under New York's plan, "New York State on PAUSE," institutions of higher education, like other $b$ sinesses and entities, were required to cancel or postpone all non-essential gatherings of individuals of any size, for any reason. ${ }^{35}$ Shortly after, in an effort to protect students, faculty, and staff, in titutions of higher education began sending students home as they imultaneously worked to develop and implement plans to conduct remote instruction. ${ }^{36}$ While many students in on-campus ho sing were sent home, another group of students living off-campus elected to stay in their housing and attend remote classes from their off-campus housing. ${ }^{37}$ This option created several,

32 Id.

3. A Schuchat, Public Health Response to the Initiation and Spread of Pandemic COVID-19 in the United States, February 24-April 21, 2020. MMWR Mo b Mortal Wkly. Rep. 2020;69:551-556. DOI: http://dx.doi.org/10.15585/mmwr mm6918e2.

34 Office of New York Governor, Executive Order No. 202: Declaring a Disaster Emergency in the State of New York (March 7, 2020), www.governor.ny.gov /news/no-202-declaring-disaster-emergency-state-new-york.

35. New York State Department of Health, New York State on PAUSE (updated Dec. 9, 2020), https://coronavirus.health.ny.gov/new-york-state-pause.

36. Office of New York Governor, Executive Order No. 202: Declaring a Disaster Emergency in the State of New York (Mar. 7, 2020), www.governor.ny.gov /news/no-202-declaring-disaster-emergency-state-new-york.

37. Dennis Q Sim and Gregory Ramkhelawan, Student Housing in the COVID19 Pandemic Era: School's Out, but for How Long?, S\&P Global (July 9, 2020), 
distinct challenges for colleges and universities as well as their host communities. $^{38}$

At SUNY Cortland, for example, while most students returned home, students that remained in off-campus housing were reminded of their responsibility as "residents of the greater Cortland comm nity" and were encouraged to follow the Executive Order regarding gatherings, social distancing requirements, limiting use of public transportation, and avoiding contact with vulnerable populations. ${ }^{39}$ A letter sent to all students from the Vice President for S udent Affairs reiterated that students who ignored or disregarded the directives could be charged through the student conduct process and could face immediate suspension. ${ }^{40}$

Syracuse University administrators struggled with how to clear out residence halls, dorm rooms, and apartments while adhering to Governor Cuomo's restrictions under "New York State on PAUSE." A letter sent to all students, parents, and families from the Interim Director of Auxiliary Services explained the University's attempts to balance the limitations on non-essential travel created by the Governor's Orders with students' need to return to campus and retrieve personal belongings in order $t$ receive a refund or credit for Spring 2020 fees. $^{41}$ As discussed below issues surrounding refunds and credits for Spring 2020 fees led to several legal challenges which colleges and universities $h \mathrm{~d}$ to face in the weeks and months after the mandatory closures. ${ }^{42}$

In New Jersey, Go ernor Phil Murphy issued a stay at home order on March 9, 2020 and issued a subsequent order on March 21, 2020 reiterating hat all in-person instruction at higher education institution was prohibited, but clarified that schools were

https://www spglobal.com/ratings/en/research/articles/200709-student-housing-in -the-covid-19-p ndemic-era-school-s-out-but-for-how-long-11566259.

38. Dennis Q Sim and Gregory Ramkhelawan, Student Housing in the COVID19 Pandemic E a: School's Out, but for How Long?, S\&P Global (July 9, 2020), https://www.spglo al.com/ratings/en/research/articles/200709-student-housing-in -the covid- 9-pandemic-era-school-s-out-but-for-how-long-11566259.

39. SUNY Cortland, Message to Students Returning to Off-Campus Housing (Mar. 23, 2020), https://www2.cortland.edu/news/detail.dot?id=117c7ce7 $-33 \mathrm{f}-4 \mathrm{a} 7 \mathrm{f}-90 \mathrm{cb}-7 \mathrm{c} 59 \mathrm{e} 47 \mathrm{f} 4 \mathrm{~b} 15$.

40. Id

4 News Staff, Coronavirus Update: Room and Board/Meal Plan Refunds and Credit Syracuse Univ. News (Mar. 25, 2020), https://news.syr.edu/blog/2020/03/25 /coronavirus-update-room-and-board-meal-plan-refunds-and-credits.

Emma Kerr, Why Students Are Seeking Refunds During COVID-19, U.S. News \& World Rep. (Apr. 22, 2020), https://www.us news.com/education/best-colleges/paying-for-college/articles/college tuition-refunds-discounts-an-uphill-battle-amid-coronavirus. 
permitted to provide food and other essential, non-educational services on a limited basis as approved by the New Jersey Department of Health. ${ }^{43}$ In response, Rutgers University did not allow tuden $\mathrm{s}$ to return to campus following spring break, but did provide students with a credit for housing, dining, and parking charges to be applied to each eligible student's account on a prorated basis starting on March 23, 2020. ${ }^{44}$

Iowa Governor Kim Reynolds issued a Proclamation of Public Health Disaster Emergency on March 9, 2020 sta ing that the CDC confirmed an outbreak of COVID-19 in at 1 ast 35 states and that multiple individuals tested presumptive $\mathrm{p}$ sitive for COVID-19 within the state of Iowa ${ }^{45}$ Shortly after, colleges and universities in the State began to close. Following the c osure of the campus at the University of Northern Iowa, administrat rs announced that credit changes and refunds would be given for fees paid for services that were unavailable due to the closures requi ed as part of the University's COVID-19 response. ${ }^{46}$ The University indicated that credits would include costs and contr cts for housing, dining and parking, as well as supplemental course $f$ es and recreation fees. ${ }^{47}$

\section{B. Questions of Refunds a d the Rise of Class Action Lawsuits}

While refunds for housing and other student services were, in some cases, granted to students sent home in March 2020, many institutions declined to $\mathrm{p}$ ovide refunds for tuition and other academic fees. ${ }^{48}$ At the Universi y of California, for example, administrators

43. Office of New Jersey Governor, Executive Order No. 107 (Mar. 21, 2020), https://nj.gov/infobank/eo/056murphy/pdf/EO-107.pdf.

44. Rutgers $U$ iversity, Information on Refunds for Student Housing, Meals, and Parking (Mar. 26, 2020), https://coronavirus.rutgers.edu /inform tion-on-refunds-for-student-housing-meals-and-parking.

45 Offi e of the Iowa Governor, Proclamation of Disaster Emergency (Mar. 9, 20 0), ttps://governor.iowa.gov/sites/default/files/documents/202003100818.pdf.

46. Uni ersity of Northern Iowa, UNI Announces Credit Changes and Refunds Du to COVID-19 Response (Mar. 30, 2020), https://insideuni.uni.edu/newsroom /uni-announces-credit-changes-and-refunds-due-covid-19-response.

7 University of Northern Iowa, UNI Announces Credit Changes and Refunds Due to COVID-19 Response (Mar. 30, 2020), https://insideuni.uni.edu/news room/uni-announces-credit-changes-and-refunds-due-covid-19-response (providing examples of the University's credits, prorated from a date of March 23 to May 8 , covered such items as housing, course and lab fees, recreation fees, and parking permit fees).

48. Emma Kerr, Why Students Are Seeking Refunds During COVID-19, U.S. News \& World ReP. (Apr. 22, 2020), https://www.usnews.com/education /best-colleges/paying-for-college/articles/college-tuition-refunds-discounts-an-up hill-battle-amid-coronavirus. 
made it clear that tuition covered the cost of instruction, rather than a particular medium of instruction, and therefore no refunds for tuition would be forthcoming. ${ }^{49}$ The University's position was based on the fact that faculty were still teaching classes and student were still taking classes, and reimbursement of tuition and oth $r$ academic fees was not warranted. ${ }^{50}$ Similar positions were taken by other institutions around the country.

As the virus spread and closures intensified, additional questions surrounding refunds and credits created other challenges including class action lawsuits. ${ }^{51}$ Questions relating to which exp ns s were "refundable" led some schools to provide "refunds in the form of lower fees or account credits for housing and service costs for the 2020-2021 academic year, with no actual refunds being provided. ${ }^{52}$ In many states, questions related to refunds on housing and student fees are rising, and class action lawsuits are being filed against a number of colleges and universities. ${ }^{53}$ As of une 2020, over 70 class action lawsuits had been filed. ${ }^{54}$ The possibility of additional COVID-19 restrictions and continuing emote instruction for several semesters was a driver for some st dents to seek restitution for tuition, student fees, room, and board through these lawsuits, with class action members typically defined as any student enrolled in the 2019-2020 academic year. ${ }^{55}$ Most plaintiffs are seeking reimbursement for costs includ ng housing, dining, and on-campus services, as well as tuition refunds on the basis that remote learning did not provide an equal form of learning to in-person education. ${ }^{56} \mathrm{~A}$ description of several illustrative reported actions follows.

49. Bob Egelko, UC Doesn't Have to Refund Student Fees for Services Reduced by COVID, C rt Rules, S.F. Chron. (Nov. 11, 2020), https://www.sfchronicle.com /news/article/UC doesn-t-have-to-refund-students-fees-for-15723257.php.

50. Id.

51. Andrew Smalley, Higher Education Responses to Coronavirus (COVID-19), National Conference of State Legislatures (July 27, 2020), https://www.ncsl.org /research/edu ation/higher-education-responses-to-coronavirus-covid-19.aspx.

52 M rgan Lewis, Colleges \& Universities Hit with Refund Class Actions While Struggling w h COVID-19 Effects, JD SuPRA (May 19, 2020), https://www.jdsupra .com legalnews/colleges-universities-hit-with-refund-92718.

53. Id

54. Anjelica Cappellino, More Than 70 Universities Sued for Refunds Following C VID-19 Campus Closures, EXPERT Inst. (updated June 25, 2020), www . xpe tinstitute.com/resources/insights/universities-sued-for-covid-19-refunds -foll wing-campus-closures.

55. Lewis, supra note 52.

56. $I d$. 
In Florida, a class action lawsuit brought by undergraduate students in the day division at Lynn University alleged that the University breached its contract with them, or was unjustly enriched, when the campus switched to remote education in March 2020 as a result of the COVID-19 pandemic. Members of the cla s action lawsuit claimed that they contracted for "live on-campus instruction and access to campus facilities" and that the University did not provide refunds for a prorated value between what the bargained for and what they received. ${ }^{57}$ The University move to di miss, claiming that the plaintiffs have not pointed to any cont actual provision that requires them to provide exclusively in-p rson education or a provision requiring a refund of fees, and further that the university policies on which the plaintiffs rely expressly state that the university will not provide refunds where operation are suspended for reasons beyond their control. ${ }^{58}$ The University also asserted affirmative defenses that the plaintiffs ratified any alleged breach and that impossibility and/or frustration of purpose bar the breach of contract claim. ${ }^{59}$

In October 2020, the federal district court, while not dismissing the complaint outright, issued a stay of discovery pending a further examination of the issues o determine whether they would be dispositive of the matter. ${ }^{60}$ However, on November 29, 2020, the Court denied the Universi y's motion to dismiss the class action complaint noting that the relationship between a private university and a student under Florida law is contractual in nature and that the terms of this relations ip can be derived from various university publications such as handbooks and catalogs. ${ }^{61}$ Since Lynn University had separa e divisions, including the undergraduate day and a different online division, the Court found that the plaintiffs sufficiently pled the existence of a valid contract for in-person education. ${ }^{62}$ The Court was clear that it was not opining on the merits of the

57 Gibson v. Lynn Univ., 2020 WL 670048 (S.D. Fla. Oct. 29, 2020).

58. Id.

59 Id.

60. Id.

61. Id.

62. Id. The court also cited to two similar Florida cases, Rosado v Barry Univ., Inc., 2020 WL 6438684 (S.D. Fla. Oct. 30, 2020) (noting the University charged more per credit for in-person courses than for online courses), and Salerno v Florida State College, 2020 WL 5583522 (M.D. Fla. Sept. 16, 2020) (noting that it was enough to establish an implied contract through college materials that discussed courses would be conducted in person and that on campus facilities would be accessible). 
case, solely on the question of whether an implied contract existed between the University and its students and concluded in the affirmative, saving for future stages in the proceeding determinations regarding the University's Force Majeure Provision in its policies the extent to which the doctrine of impossibility of performance is relevant given that the University did not close down entirely but rather moved to remote education, and the impact of order from the Florida Governor and from Palm Beach County that may have mandated certain actions. ${ }^{63}$

Another class action lawsuit was filed against No thea te $n$ University for breach of contract or, alternatively, unjust enrichment for retaining the full amount of tuition and fees for the Spring 2020 semester following a March 11, 2020 notification from President Joseph Aoun that, due to the COVID-19 pandemic, beginning on March 12, 2020, all courses would move to an online format for the remainder of the semester. ${ }^{64}$ One of $h$ class action members claimed a professor had stopped lectu ing completely after this change of teaching modality and rather emailed weekly notes to the students. ${ }^{65}$ On a motion to dismis the court agreed with the University that the plaintiffs did not establish a contractual right to in-person instruction since the University's Financial Responsibility Agreement provides that students pay for all tuition, fees, and other associated costs as a result of registering for courses and that the Agreement does not spe ify a particular method of course instruction. ${ }^{66}$

In addition to dismissing the breach of contract claim over the switch to online instruction, the court dismissed claims that plaintiffs were entitled to a return of fees including the student activity fee, the student center fee, and the undergraduate student fee since these fees re used to support certain facilities during the time students are enrolled but not to specifically gain access to these facilities. With respect to a campus recreation fee, however, which gives students admission to certain athletic events and use of athletic facilities which $\mathrm{w}$ re closed as a result of COVID-19, the court denied the mo ion to dismiss this claim. ${ }^{67}$ Lastly, the court dismissed the claim for $u$ just enrichment, since under Massachusetts law, litigants

63. Gibson, 2020 WL 7024463.

Chong v. Northeastern Univ., 2020 WL 5847626 (D. Mass. Oct. 1, 2020).

65. Id.

66. Id.

67. Id. 
may not override an express contract (the Financial Responsibility Agreement) by arguing unjust enrichment. ${ }^{68}$

Parents of students enrolled at three public universities in Arizona (the University of Arizona, Arizona State University, and $\mathrm{N}$ the $\mathrm{n}$ Arizona University) filed a class action lawsuit on behalf of all who paid the cost of room and board and/or fees for the Spring 2020 semester and who lost the benefit of such as a resul of COVID19 and did not receive an unconditional pro-rated efund. ${ }^{69}$ However, the federal court dismissed the claim on proced ral grounds since the plaintiffs failed to file a notice of claim with the State of Arizona. $^{70}$

Unlike their response to partial housing refunds and credits, most institutions did not consider refunds for tuition since educational instruction had, in fact, continued in the Spring, and institutions took active steps to prevent the expectation of refunds in the event of Fall reopening ${ }^{71}$ such $\mathrm{s}$ re-d afting housing contracts and refund policies. ${ }^{72}$ For example, the University of South Florida developed an addendum o its contract indicating that if any of its campuses had to shut down prematurely, students would not be reimbursed for housing or dining fees already paid. ${ }^{73}$ Many universities across the count y ha e included addendums into their residence-life contracts specifying that refunds will not be issued if a COVID-19 outbr ak forces campuses to close. ${ }^{74}$ The University of Maryland at Colleg Park has added the following paragraph to its housing contra t: "The University may adjust the housing services schedul contained herein, temporarily close, and/or place restrictions on use of housing facilities as necessary in the University's so e discretion to preserve the health and safety of its

68 Id.

69. Rosenkrantz v Ariz. Bd. of Regents, 2020 WL 4346754 (D. Ariz. July 29, 2020)

0. Id

71. Ass ciated Press, Unimpressed by Online Classes, College Students Seek Ref $n d s$, Voice OF Am. (May 4, 2020), https://www.voanews.com/covid-19-pandemic /unimp essed-online-classes-college-students-seek-refunds.

2 Rick Seltzer, Housing Developer Pressured Universities on Fall Plans, Inside Higher Educ. (Aug. 7, 2020), https://www.insidehighered.com/news/2020/08/07 /housing-developer-reminded-universities-about-project-debt-they-mulled-fall-pl ans.

73. Elin Johnson, Next Candidate for the Fall Chopping Block? Student Housing Refunds, Chron. Higher Educ. (July 9, 2020), https://www.chronicle.com/article /next-candidate-for-the-fall-chopping-block-student-housing-refunds.

74. Jeremy Bauer-Wolf, Some Colleges Say No to Housing Refunds This Fall, Higher Educ. Dive (June 22, 2020), https://www.educationdive.com/news/some -colleges-say-no-to-housing-refunds-this-fall/580266. 
students and the campus community." 75 The contract also reiterated that the University might not provide refunds or credits, stating, "In the event of such temporary closures, restrictions, and/or adjustments to the housing services schedule, the University shall not be obligated to issue refunds or credits, whether partial or full for such interruptions or adjustments." 76

The University of North Carolina (UNC) at Greensboro updated its COVID-19 FAQ page to state: "The UNC System issu d guidance to all its institutions about the possibility that housing and dining refunds would not be available, particularly without tate or federal financial relief, if COVID-19 further impact students and forces them to leave campuses and return to online learning." 77

Western Carolina University added languag to its housing contracts that each resident acknowledges "the o going possibility that, due to a health or safety emergency, including the COVID19 outbreak, resident may not be able to o cupy campus housing, or resident's use of campus housing facilities may be significantly restricted." ${ }^{78}$ The University also made it clear that campus housing facilities may not be available or may be significantly limited and that the institution could place restri tions on the use of housing facilities to preserve the health and safety of residents and the campus community. In the case of such losures, the University would not be obligated to issue a efund or credit. ${ }^{79}$

\section{Approaches to Reopening for Fall 2020/Spring 2021}

Approaches to campus $r$ openings continue to be influenced by CDC guidelines for IHEs, state specific reopening guidelines and other business, health and education regulations applying to higher education ${ }^{80}$ Fall 2020 operations were also influenced by evolving travel related quarantines and COVID-19 testing protocols. ${ }^{81}$ In a

75. Departmen of Resident Life, Fall 2020 Housing: Housing Addendum, Univ. of M ryland (Fall 2020), http://reslife.umd.edu/fall2020/addendum.

76. J hnson, supra note 73.

77 Id.

78 W. Carolina Univ., Residence Hall and Move-In Procedures (Fall 2020), https://www.wcu.edu/operations-procedures/move-in.aspx.

79 Id.

80. Centers for Disease Control and Prevention, Considerations for Institutions of Hi her Education (Dec. 3, 2020), https://www.cdc.gov/coronavirus/2019-ncov /co munity/colleges-universities/considerations.html.

81. Centers for Disease Control and Prevention, Domestic Travel During the COVID-19 Pandemic (updated Dec. 2, 2020), https://www.cdc.gov/coronavi rus/2019-ncov/travelers/travel-during-covid19.html. 
number of states, including New York, institutions were required to file reopening plans with the State government. ${ }^{82}$ Among the many challenges to reopening college and university campuses student housing, both on and off campus, remained a major issue ${ }^{3}$ For example, concerns arose around the need to have rooms and/ or buildings set aside for quarantine and/or isolation and to control the number and disbursement of students in bedrooms, $s$ ites, and apartments as well as how buildings with shared facilities such as bathrooms and cooking areas should operate. ${ }^{8}$ Colleges and universities were also encouraged to develop plans fo enforcement of student codes of conduct based on student violations of COVID-19 protocols and contingency plans in the event students were unable to remain in on-campus housing. ${ }^{85}$

State specific guidelines for reopening were also provided for institutions that were planning to reopen with in-person instruction in the Fall of 2020. Each set of gu delines showed a state-by-state approach to reopening, although many looked to the CDC guidelines. In California, for examp e, the Department of Public Health issued a 27-page directive regard ng COVID-19 guidance for higher education institutions. The directive was intended to help institutions as well as their communities plan, prepare, and carry out in-person instruction. The directive covered all aspects of reopening college campuses a $\mathrm{d}$ included information on required changes to dining, living options, modified lay-outs for classrooms and other common spaces and isolation criteria. ${ }^{86}$ Guidance was offered on implementing appropriate social distancing through the establishment of a tiered approach for classroom capacity, housing assignments, and student participation at various collegiate activities. The number of individuals permitted at any one location, or event, would be based on the tier number in place at any given time ${ }^{87}$ The directive also provided information on installing impermeable barriers

82. N.Y State Department of Health, Interim Guidance for Higher Education Du ing the COVID-19 Public Health Emergency (June 28, 2020), https://www.gov ernor. y.gov/sites/governor.ny.gov/files/atoms/files/Higher_Education_Detailed _Guidelines.pdf.

83. Centers for Disease Control and Prevention, supra note 80.

84. Id.

85. $I d$.

86. Cal. Dep't Pub. Health, COVID-19 Industry Guidance: Institutions of Higher Education (Sept. 30, 2020), https://files.covid19.ca.gov/pdf/guidance-higher -education--en.pdf.

87. Id. For example, under Tier 1 phase ("Widespread"), only outdoor meal operations would be permissible take-out and delivery only. Similarly, under Tier 1, in-person lectures would be prohibited. 
across campuses, improving ventilation systems, and working with the appropriate local health officials and members of the campus community to maintain healthy operations for students, faculty, and staff. Finally, the directive recommended that overall coordination of these efforts should be directed by a designated COVID-19 Poi $t$ of Contact. ${ }^{88}$

In New York, Governor Cuomo issued guidance for mitigation actions that schools must take when the infection rate ris $s$ above certain levels. Under New York's reopening strategy, a threshold was set that required colleges with 100 positive COVID-19 cases or with a number of cases that equaled 5 percent of an institution's population or more, to move to remote learning for two weeks, at which time the situation could be reassessed. ${ }^{89}$ Moreover, under the Interim Guidance, Governor Cuomo provided i struction on limitations for on-campus activities as well as required COVID-19 testing on campuses. The guidelines cover capacity testing, residential living, operational activity, monitoring, a d containment..$^{90}$

In addition to confronting the cha enges of reopening in the Fall of 2020, many institutions continue to grapple with the challenges of reopening in the Spring of 2021. For example, at Harvard University, administrators recently $n$ tified students that the institution would permit more undergraduates to live in on-campus housing for Spring 2021, and the Uni ersity has committed to filling all 3,100 dorm rooms as singles this coming spring..$^{91}$ The University's decision was based on lower-than-expected COVID-19 numbers in the fall and a positivity rat far below the surrounding area. ${ }^{92}$ However, in balancing public $\mathrm{h}$ alth considerations with academic priorities, Harvard has deci ed to open these rooms only to seniors who are

88. Id. ("Designate an administrator or office to be responsible for responding to COVID-19 ncerns. All IHE students, faculty, and staff should know who they are and how to con act them. The liaison should be trained to coordinate the investigation, $\mathrm{d}$ cumentation and tracking of possible COVID-19 exposures, in order to appropriately instr ct close contacts to quarantine, and notify local health officials, staff, and $\mathrm{f}$ milies in a prompt and responsible manner.").

89. Office of New York Governor, Governor Cuomo Issues Guidance for Infe tion Rates on College Campuses Following Reports of Students at Large Ga herings (Aug. 27, 2020), https://www.governor.ny.gov/news/governor-cuomo -issues guidance-infection-rates-college-campuses-following-reports-students.

9 N.Y. State Dep't of Health, Supplemental Guidance for COVID-19 Containment at Higher Education Institutions During the Public Health Emergency (Aug. 8, 2020), https://www.governor.ny.gov/sites/governor.ny.gov/files/atoms/files $/ \mathrm{H}$ herEducationSupplementalGuidance.pdf.

91. Harvard Univ., Harvard College Spring 2021 Plan (Dec. 1, 2020), https:// ww.fas.harvard.edu/news/harvard-college-spring-2021-plan.

92. Id. 
graduating and students with special academic circumstances. ${ }^{9}$ Under the Spring 2021 Plan, for example, students who are juniors with a specific need to be on campus to access academic $r$ sourc $s$ needed to launch independent studies or students in dista time zones that face challenges with synchronous learning which require real-time academic engagement would qualify for housing. ${ }^{9}$ Harvard acknowledges that not all students may return to cam us in the Spring, but stresses that additional steps will be taken to assist these students' return to campus as soon as practicable.

At the University of Arizona, administrato s are focusing on new testing requirements that they believe will allow more students to live on campus and/or attend in-person classes during the spring semester. The new COVID-19 testing standards will require weekly tests of all students who live in dorms or who attend in-person classes on the main campus. ${ }^{95}$ To enforce this requirement, the University has indicated that students who fail to comply will lose their access to the University's Wi-Fi network ${ }^{96}$ The University will also begin offering additional, new methods of esting in order to increase test response rates and times. ${ }^{97}$ As di cussed below, however, COVID-19 testing continues to create one of the more significant issues for colleges and universities attempting to reopen.

\section{A. COVID-19 Test ng on Campus}

One of the relevant, and in many ways most controversial, issues related to reopening in Fall 2020 was COVID-19 testing. Colleges and universities ha had to balance cost, availability, implementation strategies, effectiveness, privacy, and other complex legal and policy issues An analysis of 1,400 colleges' testing policies conducted by Davidson College and analyzed by National Public Radio found that just 25 percent of institutions were conducting mass scr ning $\mathrm{r}$ random surveillance testing in the fall..$^{98}$ At the start

$93 I d$.

94. $I d$.

95 Alexis Blue, UArizona to Roll out New COVID-19 Test, Enhanced Requirements in Spring, Univ. Ariz. News (Dec. 7, 2020), https://news.arizona.edu/story /uarizona-roll-out-new-covid-19-test-enhanced-requirements-spring.

96. Id.

97. $I d$.

98. Elissa Nadworthy \& Sean McMinn, Even in COVID-19 Hot Spots, Many Colleges Aren't Aggressively Testing Students, NPR (Oct. 10, 2020), https://www .npr.org/2020/10/06/919159473/even-in-covid-hot-spots-many-colleges-arent -aggressively-testing-students. The data from more than 1,400 colleges were compiled by the College Crisis Initiative at Davidson College and analyzed by NPR. 
of the fall semester, for colleges and institutions that were opening for in-person instruction, less than a third required on-going testing for students. ${ }^{99}$ The data, collected by the Davidson College Cris s Initiative (C2I), was designed to enhance understanding of institu tions' responses to the COVID-19 pandemic and included data $n$ four-year public and non-profit colleges for every day in the $\mathrm{m}$ nth of March 2020. ${ }^{100}$

The CDC has also provided information on testing and s reening as well as outbreak response for IHEs and encourag d exp nded and widespread testing to help college and university admini trators protect students, faculty, and staff from COVID-19 infections and slow the spread of the virus. ${ }^{101}$ The CDC website encourages administrators to consider a "tiered approach" to test ng in the context of an outbreak. ${ }^{102}$ This tiered approach, which the CDC stresses is necessary to provide a comprehensive plan for addressing COVID-19 infections, might involve rapid case testing incr ased contact tracing, and review/alteration of mitigation strategies as circumstances evolve. ${ }^{103}$ The CDC also offers examples of successful entry and periodic screening strategies and provides information on the likelihood of, and factors contribut ng to off-campus transmission. ${ }^{104}$ Finally, the CDC's testing guidel nes include strategies for continuing surveillance, diagnosis, and screening. ${ }^{105}$

As a recent report pub shed by the National Academies of Science, Engineering, and Medicine highlights, COVID-19 testing occurs in myriad circumstances in a wide array of institutions. Colleges and universities no only vary in size and availability of resources, but also in location, aspects of surrounding communities, and demogr phics. ${ }^{1}$ In determining appropriate testing strat-

99. Id.

100. David o College, The College Crisis Initiative at Davidson College (2020), https://collegecrisis org From March 6 to March 12, 2020, nearly two-thirds of all four-year in titutions announced plans to transition online; our dashboard will allow for researche s, policymakers, students and their families, and administrators to understa $\mathrm{d}$ how colleges made those decisions.

101. The Ce ter for Disease Control and Prevention, Testing, Screening, and Outbreak Resp nse for Institutions of Higher Education (IHEs) (updated Oct. 21, 2020), http ://www.cdc.gov/coronavirus/2019-ncov/community/colleges-universities /ihe-tes ing.html.

12 Id.

103 Id.

104 Id.

5. Id.

106 Nat'l Academies of Scis., Eng'g, \& Med. 2020, COVID-19 Testing Strategies for Colleges and Universities. Wash., D.C. The National Academies Press. https://doi.org/10.17226/26055. 
egies, colleges and universities should consider such factors as their position as primarily commuter or residential campuses, geographic region, and data on COVID-19 incidences in the area in determining appropriate strategies, which "should be chosen to mat $\mathrm{h}$ the needs and circumstance of the particular institution." 107 The report encourages institutions to determine lessons learned from the various testing strategies implemented to date and to modify testing strategies as needed for reopening in the Spring of 2021.

In practice, schools have developed different approaches to testing. ${ }^{108}$ At Clemson University, for students living in on-campus housing, testing is required on a weekly bas $\mathrm{s}$ and students who live off campus are subjected to random tests to limit the spread of COVID-19 on campus and in the community. ${ }^{109}$ Clemson also created an interactive "dashboard" for information related to COVID-19 for students, faculty, and staff that contained the latest information based on populati $\mathrm{n}$ surveillance testing, mandatory return-to-campus testing fo students and employees, and symptom-based testing. ${ }^{110}$ Administ ators at Clemson, following the Clemson University Campus Opening Plan, have insisted that such testing is necessary to help model and inform college response and decision-making and to identify quarantine and isolation needs, such as the number of beds and spaces needed. ${ }^{111}$

At Iowa State University, students were required to be tested before moving into their residence halls. ${ }^{12}$ The University employed COVID-19 testing of select students, with such students randomly chosen for asymptomatic testing being informed via email or text message that included instructions on when and where the testing would occur ${ }^{113}$ The University encouraged compliance by rewarding

107 Nat'l Acads. of Scis., Eng'g, \& Med. 2020, COVID-19 Testing Strategies for Colleg s and Universities. Washington, DC. Nat'l Acads. Press, https://doi .org/10 17226/26055.

108. Eli abeth Redden, Disparities in Testing, Inside Higher Education (Aug. 21, 2020), https://www.insidehighered.com/news/2020/08/21/covid-19-testing-strat egies-v ry-widely-across-institutions.

09. Clemson University, COVD-19 Dashboard (updated Dec. 7, 2020), https:// www.clemson.edu/covid-19/testing/dashboard.html.

110. Id.

111. Clemson University, Campus Opening Plan (Sept. 10, 2020), https://media .clemson.edu/covid/documents/sept-opening-plans.pdf.

112. Vanessa Miller, Iowa State to Start Random Student COVID-19 Testing, GazeTte (Oct.10, 2020), https://www.thegazette.com/subject/news/education /university-iowa-students-random-coronavirus-testing-20201010.

113. Iowa State University, COVID-19 Response (Feb. 29, 2020), https://web .iastate.edu/safety/updates/covid19. 
students who cooperate with gift cards obtained through a raffle. ${ }^{114}$ In contrast, the University of Iowa and the University of Northern Iowa only offer testing for symptomatic students, faculty, and sta $\mathrm{f}$ or those who had close contact with a positive case. ${ }^{115}$

In New York, Governor Cuomo required public and private col leges and universities to report daily to the Department of Health the number of positive COVID-19 cases for all students and staff, with the information gathered shared publicly in the "COVID-19 Report Card." 116 While there was no mandate to test tuden s and staff in advance of Thanksgiving in November 2020, governors from seven Northeast states encouraged colleges and universities to test students before they left campus to go to their home communities. ${ }^{117}$ State University of New York Cha cellor Jim Malatras announced that students were required to have a negative COVID19 test before they could leave campus in November, ${ }^{118}$ and that following the Thanksgiving break, the semest $\mathrm{r}$ would be completed remotely with no return to campus. ${ }^{119}$ In North Carolina, Governor Cooper announced the availability of free rapid COVID-19 tests for college campuses to test students prior to departing for Thanksgiving. ${ }^{120}$ As part of the plan to of er in person instruction in Spring 2021, the University of Nebraska Lincoln announced a mandatory COVID-19 testing program for students, faculty, and staff prior to the start of classes and ev ry two weeks thereafter. ${ }^{121}$ Students will be required to agree to the "Co nhusker Commitment," affirming

114. Iowa State Univers y, Lett $r$ from the Office of President (Oct. 9, 2020), https://www.president.iastate edu sites/default/files/communications/President's $\% 20$ Messages/FY21/2020.10 9-Student-testing.pdf.

115. Univ. of Iowa FAQs (Fall 2020), https://coronavirus.uiowa.edu/faqs

116. New York Stat Department of Health, COVID-19 Report Card (updated December 10, 2020), https //schoolcovidreportcard.health.ny.gov/\#/home.

117. Carly Sitrin, Northeast Governors Call on Colleges to Provide Students with Covid Testing, Poltico New Jersey (Nov. 18, 2020), https://www.politico.com /states/new-jersey/ to y/2020/11/18/northeast-governors-call-on-colleges-to-pro vide-students-with-covid-testing-1337018.

118. The State University of New York, SUNY Adopts System-Wide Policy Requiri g All On-Campus Students to Test Negative for COVID-19 Prior to Tha ksgivi g Break (Oct. 27, 2020), https://www.suny.edu/suny-news/press -releases/10 20/10-27-20/covid-test-thanksgiving-break.html.

119 Id.

120. Office of the Governor of North Carolina, North Carolina Provides COVID-19 Tests to Colleges, Universities Across the State to Support Testing Students Before Thanksgiving (Nov. 12, 2020), https://governor.nc.gov/news/north carolina-provides-covid-19-tests-colleges-universities-across-state-support-testing.

1. Troy Fedderson, University Readies for Mandatory COVID-19 Testing: Spring Semester Plans Include Shift to Saliva-Based Testing Processed in On-Campus Lab, Neb. Today (Dec. 8, 2020), https://news.unl.edu/newsrooms/today/article/uni versity-readies-for-mandatory-covid-19-testing. 
they will agree to adhere to the testing program and health and safety measures. ${ }^{122}$

\section{B. Fall 2020 Reopening Housing Issues}

As with other aspects of reopening such as testing, universiti s and colleges struggled with how to reopen safely and provide housing options that addressed the concerns of the campus and the larger community. The University of Arizona created guidelines for students living on campus in areas where individuals may have roommates and where individuals may live i group spaces. ${ }^{123}$ The guidelines provided on the University of Arizona Living in the Dorms Fall 2020 website require students to arrange beds so students have as much space between beds a possible and to sleep facing away from other students, rearrange other furniture to maintain 6 feet of distance between student and rohibit visitors or guests into rooms or common areas. ${ }^{124}$ The guidelines also provide information on what to do if a student is endangered by the actions or inactions of roommates or oth s living with the student and what to expect if quarantined or moved to isolation. ${ }^{125}$

Northwestern University provided a dashboard that contained general information on the latest COVID-19 updates regarding on-campus living as well as information for non-residential students. ${ }^{126}$ The University's approach also incorporates procedures on quarantining and isolation, when necessary. ${ }^{127}$ Specifically, the University requires student to quarantine or isolate if, through contact tracing, it was dete mined the student was a close contact of a student who tested positive or if the student themself tested positive. ${ }^{128}$ This quaran ine and isolation housing was provided for undergraduate students living in residence halls and residential colleges, and

122. Univ. of Nebraska, Cornhusker Commitment (Spring 2021), https:// co id19.unl.edu/we-are-cornhusker-committed.

123. Univ. of Arizona, Coronavirus (COVID-19) On-Campus Housing FAQS (updated Nov. 30, 2020), https://housing.arizona.edu/coronavirus-covid-19-campus -housing-faqs.

124. Univ. of Arizona, Living in the Dorms Fall 2020 (Fall 2020), https://hous ing.arizona.edu/sites/default/files/sites/default/files/Dorm_Living.pdf.

125. Id.

126. Nw. Univ., COVID-19 Housing Site for Residential Services (Fall 2020), https://sites.northwestern.edu/covid19housing.

127. Nw. Univ., Quarantine \& Isolation Housing (Fall 2020), https://sites.north western.edu/covid19housing/quarantine-isolation-housing.

128. Nw. Univ., COVID-19 Housing Site, supra note 126. 
the University indicated it would continually update its COVID-19 procedures with updates being posted on the website. ${ }^{129}$

The University of South Florida, like many institutions, instituted a phased approach to reopening. This allowed the University o pre pare for the resumption of normal operations while continuing $o$ limit exposure of returning students and employees and reducing community transmission. ${ }^{130}$ Opening under Phase II, which allowed for up to 50 percent of staff to return to campus, the $U$ iversity was able to begin normal operations of critical services wi h mitigation measures in place. ${ }^{131}$ For example, classes and o her cur iculum requirements, under Phase II, were delivered through combination of face-to-face, hybrid, and online instruction while residence halls opened with new health and safety policies in place. ${ }^{132}$ Finally, the University created isolation and quarantine pro ocols for students in on-campus housing, and links to the Studen Health Services protocols were provided to students detailing nstructions and expectations if isolation in University housing w s required. ${ }^{133}$

Similarly, the University of Minnesota sed a tiered or phased approach to reopening, with a particular focus on student housing and on-campus activities. ${ }^{134}$ Known as he Maroon and Gold Sunrise Plan, the protocol described the teps tudents living in University residence halls were required to follow as they returned to campus. ${ }^{135}$ As of October 13, 2020, $\mathrm{r}$ sidence halls were placed in Step Three of the Plan which permitted two guests per assigned resident in the room at any one time and did not allow guests from outside the building community. ${ }^{136}$ Although students had full access to campus and the surrounding ommunity in this third phase, students were required to retur to the residence halls each night by midnight. ${ }^{137}$ For students living in on-campus apartments or in off-campus

129. Nw. Univ., Quarantine \& Isolation Housing, supra note 127.

130. Univ. of S. Fla., Concept of Operations \& Phases (Aug. 7, 2020), https:// www.usf edu/coronavirus/returning-to-campus/concept-of-operations-phases.aspx.

1 1. Id.

132. Id.

133. Univ of S. Fla., USF Housing COVID-19 Isolation FAQ (2020), https:// ww usf.edu/housing/resources/covid-19-isolation-faq.aspx.

134. Univ. of Minn., Housing Coronavirus (COVID-19) Updates (July 8, 2020), http ://housing.umn.edu/covid-19.

135 Univ. of Minn., Maroon and Gold Sunrise Plan \& Housing (updated Nov. 25, 20 0), https://housing.umn.edu/mg-sunrise.

16 . Univ. of Minn., Fall 2020 FAQ (updated Nov. 20, 2020), https://housing umn du/fall2020.

137. Univ. of Minn., Maroon and Gold Sunrise Plan, supra note 135. 
housing, although the Plan did not apply to them, the University did recommend that they minimize their on-campus movement and follow all mitigation strategies related to wearing masks, phy ic 1 distancing, and avoiding gatherings.

\section{Enforcement and Student Violations}

Student violations of university and college COVID-19 rules and guidelines have created a different set of legal and policy issues for these institutions. ${ }^{138}$ Enforcement guidelines fro several colleges and universities demonstrate the challenge found in modeling appropriate student behavior in the face of COVID-19 restrictions. For example, at the University of Iowa, challenges exist around enforcement of the procedures incorporated into the student agreement put in place to allow the reopening of the campus. On October 9,2020 , it was reported that five sororities and one fraternity at the University of Iowa were placed on su pension while administrators investigated allegations that the Greek chapters violated prohibitions against parties and alcohol or requirements of the campus' COVID-19 student agreemen ${ }^{139}$ Reports of the suspensions came as the campus tally for COVID-19 cases rose, bringing the total number of cases for the seme ter through October 9 to 2,100. ${ }^{140}$

At the Universi y of Minnesota, the administration created procedures for reopening hat implemented a phased approach for both on-campus and off-campus students. The Sunrise Plan also provided details for the e forcement of the restrictions necessary to support the phased opening ${ }^{11}$ Specifically, students who did not comply with the "s ay home" orders or violated other University policies would face disciplinary action up to and including termination of

138. Numerous articles across the nation have been written that detail students' fail re to obey COVID-10 regulations and campus policies, demonstrating the difficulty institutions of higher education are having in preventing the spread of COVID-19. See https://www.washingtonpost.com/education/2020/09/24 /co onavirus-college-student-party-gatherings; https://www.texastribune.org/2020/09 /08/texas-universities-coronavirus-parties/and https://abcnews.go.com/US/covid-19 -quad-colleges-crack-student-parties-virus/story?id=72499108.

139. Vanessa Miller, Six University of Iowa Greek Chapters on Interim Suspension Following COVID Complaints, GAZETTE (Oct. 9, 2020), https://www.thegazette .com/subject/news/education/six-university-of-iowa-greek-chapters-on-interim -suspension-following-covid-complaints-20201009.

140. Miller, supra note 139.

141. Univ. of Minn., Maroon and Gold Sunrise Plan, supra note 135. 
their housing contracts. ${ }^{142}$ The Plan made clear that students would be eligible for contract termination after two violations of the Plan. ${ }^{143}$

Perhaps one of the more telling examples of a violation of an IHE's attempt to reopen occurred at Syracuse University, at the start of the Fall semester. In August, just a week before the start of classes, students - who were quarantined upon arrival - held la ge parties in violation of protocols in place to limit the size of gatherings to comply with New York State law. ${ }^{144}$ According to officials at the University, videos and pictures on social $\mathrm{m}$ dia how over 100 students, including some not wearing masks and not adhering to social distancing measures, gathering on campus. ${ }^{145}$ A University administrator, in a public letter, reprimanded first-year students who gathered on the campus quad in hordes during the night, throwing the feasibility of an on-campus semester into eopardy. ${ }^{146}$ The letter indicated that an investigation was on-goi $\mathrm{g}$ and that students who were found to have violated University policy would be referred to the student conduct process. ${ }^{147}$

Following the suspension of three tudents at New York University for hosting and attending off-campus gatherings during the summer of 2020 in violation of the University's COVID-19 policies, the students filed petitions (which were consolidated by the trial court), seeking to ov turn the suspensions alleging they were arbitrary, capricious, and cons ituted an abuse of discretion. ${ }^{148}$ Following a campus hearing (conducted via Zoom), where each student admitted to attending off-campus gatherings without wearing masks and observing social distances, each student was found to have violated sections B1 and E1 of the NYU Student Conduct Policy which state:

142. Id

143. Id.

144. Chris Carlson, Videos Show Large Gathering of Syracuse University Stud nts o Quad, Syracuse.com (Aug. 20, 2020), https://www.syracuse.com /cor navirus/2020/08/videos-show-large-gathering-of-syracuse-university-students -on-qu d-as-students-return-this-week.html.

1 5. Id.

146 Christopher Gavin, 'Be Better': In Public Letter, Syracuse Official Lambasts Selfish' First-Year Students, Boston.com (Aug. 20, 2020), https://www.bos ton om/news/coronavirus/2020/08/20/syracuse-university-letter-coronavirus/amp.

147 Id.

148. Santonocito v. NYU, 2020 WL 6161628 (Sup. Ct. New York Co., Oct. 21, 2020). 
University Student Conduct Policy/B1: Engaging in or threatening to engage in behavior that, by virtue of their intensity, repetitiveness, or otherwise, endang or compromise the health, safety or well-being of oneself, another person, o the general University community.

University Student Conduct Policy/E1: Disorderly, disruptive, or an gonizing behavior that interferes with the safety, security, health or welfar of the community, and/or regular operation of the University. ${ }^{149}$

In addition to the suspension for the Fall 2020 semester, although the students were eligible to return for the Sp ing 2021 semester, they remain on probation until August 2021, and each had to submit a research and reflection paper about the role of young people in the transmission of COVID-19. ${ }^{150}$ The students appealed the findings and the sanctions claiming that the above cited sections of the Code did not advise anyone that failing to wear a mask or to remain socially distant off campus in private residences would violate the sections and argued that the fact that all hree students tested negative after the gatherings was not onsidered and that the sanctions were substantially disproportionate to the charged offense. ${ }^{151}$

The University denied the appeal and the students turned to the Court. The trial court agreed with the students that a July 30, 2020 notice to the entire stude $t$ body about returning to the campus in the fall "did not give pre-conduct notice that a rooftop private gathering over the $\mathrm{s}$ mmer break could result in sanctions including suspension." 152 The Court also reviewed a July 30, 2020 letter sent to students, parents, and guardians, the August 5, 2020 University COVID-19 Policy and an August 14, 2020 written communication to all students from the Director of the Office of Student conduct and Community Standards and concluded that these communications were all aimed at student conduct for the forthcoming academic year and failed to provide these students with appropriate pre-conduct notice. ${ }^{153}$ The court noted that the judiciary in New York ffords great deference to decisions of institutions of higher e ucation and that when reviewing nonacademic institutional disciplinary matters, the review is limited to whether the institution adhered to its own published rules and guidelines and was not 
arbitrary or capricious. ${ }^{154}$ Writing in dictum, the Court determined that, had the University given pre-conduct notice to the students, it would have provided a rational basis for discipline and that sanctions would have been upheld. ${ }^{155}$

The costs of outbreaks are high for institutions and students alike. In addition to the large number of lawsuits, college and university administrators are faced with increasingly difficult de isions related to COVID-19 cases and community spread. ${ }^{156}$ A SUNY Oneonta, critics contend that the president was removed after failures to address the rising case numbers on campus. ${ }^{157}$ The hancellor of the SUNY system announced that Barbara Jean Morris would be replaced as Oneonta's president in order to address shortcomings in the college's response to COVID-19 and to finalize the college's plan for Spring 2021. ${ }^{158}$ During the fall, SUNY Oneonta shifted to remote learning only one week into the semester after it tested students on campus and found that nearly 700 tested positive. ${ }^{159}$ Many argue that the closure was inevitable in light of the fact that, unlike some SUNY institutions, Oneonta had not required tests in advance and had not tested students upon their return to campus. ${ }^{160}$

154. Id.

155. Id.

156. Rich Seltzer, Coun y COVID Counts Often Rose After Colleges Started Classes, Inside Higher Educ (Sept.25, 2020), https://www.insidehighered.com /news/2020/09/25/dat reveal-complex-picture-between-colleges-and-county -covid-19-case-counts.

157. Doug Lederman, COVID-19 Roundup: President Out After College's Poor Respons, Inside Higher Educ. (Oct. 16, 2020), https://www.insidehighered .com/news/2020/1 /16/covid-19-roundup-president-loses-her-job-college-closes -and-send -st dents-home?utm_source=Inside+Higher+Ed\&utm_campaign =f27826d3d7-DNU_2020_COPY _02\&utm_medium=email\&utm_term=0_1fc bc0 421-f2 826d3d7-199790317\&mc_cid=f27826d3d7\&mc_eid=ef35c4ecbc.

158. Doug Lederman, A President Loses Her Job; A College Closes and Sends Stud nts H me, Studently (Oct. 16, 2020), https://studently.org/2020/10/16/a-pres iden loses-her-job-a-college-closes-and-sends-students-home.

159. State Univ. of New York, Chancellor Malatras Directs SUNY Oneonta to Transition All Students to 100\% Remote Learning Off Campus for Fall Semester Following Nearly 400 COVID-19 Cases (Sept. 3, 2020), https://www.suny.edu/suny news press-releases/09-2020/9-3-20/oneonta-transitions-remote-learning.html.

0 . Lucas Day, State Forces SUNY Oneonta to Switch to Online Learning fo Fall Semester, Finger Lake Daily News.com (Sept. 3, 2020), https:// ww.fingerlakesdailynews.com/2020/09/03/state-forces-suny-oneonta-to switch-to-online-learning-for-fall-semester. 


\section{Is Student Congregate Housing a Conduit for COVID-19 Transmission?}

By December 11, 2020, almost 400,000 confirmed cases of COVID19 were reported at roughly 1,800 college and university ampuses, with 85 schools reporting at least 1,000 cases and more than 680 schools reporting at least 100 cases. ${ }^{161}$ A recently published study that was designed to review the incidence of COVID-19 among undergraduate students in the fall of 2020, collected data through November 2020 from nine institutions of higher educa ion in the greater Boston area and four institutions from outside of that region and concluded that most of the students contracted the virus outside of the dorm-residential setting with minimal community transmission within the congregate on-campus student housing. ${ }^{162}$ The authors noted a correlation between more frequent testing (more than once a week) and lower infection rate in the undergraduate students living on-campus; however, they determi ed that the correlation was insufficient to conclude that "higher testing cadence alone directly suppressed COVID-19 transmi ion ${ }^{163}$ For example, the researchers commented that it was possible that schools that tested more often may have also impl mented more restrictive social interaction policies, and such institutions may also have made certain upgrades to campus ventila ion systems to help lower infection rates. ${ }^{164}$ To further accurately assess a more complete picture of factors that could lead to lower ransmission rates among students residing in on-campus housing, the research called for open access to standardized data structures including:

- informatio on student housing such as number of students, housing density, numbers per bedroom, numbers per bathroom, etc.;

- fa e mask policies and compliance estimates;

161. Tracking the Coronavirus at U.S. Colleges and Universities, N.Y. TIMES (Dec. 11, 2020), https://www.nytimes.com/interactive/2020/us/covid-college-cases -tracker.html.

162. Christopher W. Stubbs, Michael Springer \& Tasha S. Thomas, The Impacts of Testing Cadence, Mode of Instruction, and Student Density on Fall 2020 COVID-10 Rates on Campus, MedrXIV (Dec. 4, 2020), https://www.medrxiv.org/content/10.11 01/2020.12.08.20244574v1.full.pdf.

163. Id.

164. Id. 
- daily testing records and associated attributes (numbers tested from on-campus and off-campus residential populations, undergraduate, graduate, post-docs, faculty, staff, and professional student status, etc.);

- daily logs of residential and non-residential students in isol tion and quarantine;

- modes of instruction such as distributions of number $f \mathrm{~s} \mathrm{u}-$ dents engaged in in-person, hybrid, and fully remot le rning;

- metrics that capture the social limitations put in place $y$ the institution and compliance indicators; and

- residential ventilation characteristics, such as ubic feet per minute of HEPA-quality filtered air exchange. ${ }^{165}$

\section{Conclusion}

There is little doubt that COVID-19 ha been the single greatest disrupter in higher education. Presiden s and their cabinets, along with Boards of Trustees, have had to navigate in unchartered waters making difficult decisions balancing public health and safety with the full array of educational acti ities offered throughout the campus. Decisions have impacted the economic health, and sometimes viability, of institutions, a ng with the economic security of campus employees. Campuses took varying approaches to meeting the challenges, often dependent upon the ever-evolving governmental policies at the federal, state, and local levels. The myriad legal and policy issues identified in this brief article just begin to scratch the surface of what $\mathrm{i}$ expected to unfold. More lawsuits are expected to be filed, and legal counsel and their clients still anxiously await the outcomes of dozens of lawsuits making their way through the courts. With a ew Administration in the White House at the start of 2021 Dr. Anthony Fauci has alerted higher education leaders to expec more centralized coordination of COVID-19 policies, signali $\mathrm{g}$ a more uniform federal approach as opposed to the haphaz rd sta e-by-state policymaking experienced to date. ${ }^{166}$ Rochelle Walensky, President-Elect Biden's choice to head the Centers for

166 Hilary Burns, Fauci to Colleges: Expect a More Centralized Covid Policy Under Biden, Bos. Bus. J. (Dec. 9, 2020), https://www.bizjournals.com/bizjournals news/2020/12/09/fauci-colleges-expect-covid-policy-central-biden.html. 
Disease Control, ${ }^{167}$ wrote in September 2020 that the decision of over one third of colleges and universities to fully reopen for the Fall 2020 semester was a risky disaster. ${ }^{168}$ While the anticipated rollout of vaccines through the early part of 2021 has led scho 1s such as California State University to already announce plans o return to in-person, on-campus instruction in Fall 2021, ${ }^{169}$ at press time, it is still unclear what this will mean for higher educatio as a whole. Many questions remain, for example, related to the availability of possible immunizations and whether such immuniza ions can be required by colleges and universities, and the answers to such questions may have far-reaching impacts. The COVID-19 pandemic will continue to challenge the higher education sector for years to come in terms of safe returns to campus, pol cies to protect the campus and surrounding communities, changing perceptions of the value and quality of distance education, and he economic impact of new policies, ongoing litigation, consum $\mathrm{r} d$ mands, and compliance with government mandates. The resiliency of higher education leadership will continue to be tested unlike no other time in history.

167 Press Release, Biden-Harris Transition, President-Elect Joe Biden An ounces Key Members of Health Transition Team (Dec. 7, 2020), https:// buildbackbetter.gov/press-releases/president-elect-joe-biden-announces-key members-of-health-team.

168. Gavin Yamey \& Rochelle P. Walensky, The Key is to Curb Community Transmission Then Provide Frequent Testing, BMJ (Sept. 1, 2020), https://www.bmj .com/content/370/bmj.m3365.

169. Cal. State Univ., California State University Anticipates Return to In-Person Coursework for Fall 2021 Term (Dec. 9, 2020), https://www2.calstate.edu/csu -system/news/Pages/California-State-University-Anticipates-Return-to-In-Person -Coursework-for-Fall-2021-Term.aspx. 
